\title{
Weighing Materials in Rare Book and Manuscript Libraries as a Security Measure against Theft and Vandalism
}

RARE BOOK AND MANUSCRIPT MATERIALS have long been and continue to be obvious targets for thieves. ${ }^{1}$ No system for completely deterring or detecting such people has ever been devised, despite numerous security improvements over the years and heightened awareness of the problem among custodians of these materials. Any number of highly effective measures to prevent theft seem obvious and well known. One could, for example, completely collate every book before it was issued to a reader and then collate it again when the book was turned back in. Or, one could completely inventory the contents of a manuscript folder when it was issued and then review the contents leaf by leaf when the folder was returned. Other means of detection and deterrence use CCTV cameras to monitor reading room activities. As effective as such methods might be, they are often not practical, little used, or not employed properly. They are expensive, time consuming, and require more staff than most rare book and manuscript repositories could ever hope to muster. Reading room security, therefore, continues to depend on staff vigilance as the primary method of deterrence and detection. ${ }^{2}$

1. I am grateful to my sister, Mary Beth Wilkie, a medical researcher at the University of North Carolina at Chapel Hill, for her expert technical guidance and advice on scales, their physical characteristics, their use, and proper weighing techniques. In many ways, she opened my eyes to the security possibilities of the instruments. I am also grateful to Saundra Taylor, Becky Cape, and Michael L. Taylor of the Lilly Library, Indiana University; Tim Murray of the University of Delaware; and Bob Anthony and Nicholas Graham of the University of North Carolina at Chapel Hill, for their assistance. Finally, I wish to thank Arnold Breisblatt of the Sartorius Company for his assistance in providing some of the figures for this article.

2. Most of the information in this paragraph is anecdotal. Very little actual research has been done into effective reading room security methods beyond the stage of general recommendations that can be implemented in various ways depending on an institution's circumstances. Even CCTV systems, generally believed to help with deterrence and detection, have had a mixed acceptance. For example, they did not deter map thief E. Forbes Smiley, who stole from reading rooms equipped with them. When suspicions originally fell on Smiley in Yale's Beinecke Library, the CCTV system was turned off, although Smiley would have had no way of knowing that. For the most current general security guidelines, see ACRL/RBMS Guidelines for the Security of Rare Book, Manuscript, and Other Special Collections (Chicago: ACRL, 2006) and their Guidelines Regarding Thefts in Libraries (Chicago: ACRL, 2003). For a listing of reported library thefts going back to the mid 1980s, see "Incidents of Theft" under the Security Committee at the RBMS homepage: www.rbms.org. 
A method of detection that is effective, accurate, and relatively inexpensive is offered by weighing materials when they are issued to a reader and then reweighing them when they are returned. The primary expense in setting up such a system is acquiring the proper scale (or "balance," as the device is technically called) and maintaining it. Appropriate scales are easy to use, give clear indications if something has been removed from or added to a volume or folder, are extremely sensitive, and present few practical problems. The purpose of this article is to explore issues and methods surrounding the use of such a system as a deterrent and detection method against theft and vandalism. In part, some of what is proposed here is theoretical. Appropriate scales are sensitive enough to be of real use in detecting theft and vandalism; their use, however, is hardly widespread. The author has knowledge of two major libraries that use this method for detecting such problems, although neither will allow itself to be identified publicly for security reasons. It is hoped that the considerations presented here will induce other libraries to attempt this method so that perhaps better knowledge may be gained about its efficacy. ${ }^{3}$

\section{The Scale}

Often used in scientific and industrial settings, scales are available with a wide range of features and at various prices. In selecting a scale, the chief consideration for a library is to choose one that will accurately weigh within desired tolerances the majority of materials issued to readers. Although scales are available that will weigh the heaviest items, such as an entire book truck of manuscripts, the primary issue facing libraries in the selection of such a scale is its sensitivity range. Two types of scales are generally available that might be appropriate to rare book and manuscript considerations.

The first type of scale is metric and weighs in grams (hereinafter usually abbreviated gm), a standard scientific measurement equal to one thousandth of a kilogram, itself equal to 2.2046 pounds avoirdupois. (One ounce avoirdupois contains $28 \mathrm{gm}$.) Even the simplest of these scales will weigh grams at the hundredths level (i.e., $0.00)$; many will weigh in milligrams (i.e., 0.000).

The second type of scale is avoirdupois and weighs in pounds and ounces. In the United States, practically the only country in the world with a genuine need

3. In preparing this article, I was aware of several real-world opportunities to test this system against books that had actually been vandalized. A few libraries flatly refused to allow my experiments or even discuss the matter with me. I was, however, fortunate to discover cooperative libraries that had not reattached maps removed by Gilbert Bland (the thief featured in Miles Harvey, The Island of Lost Maps: A True Story of Cartographic Crime [New York: Random House, 2000]). See Appendix II for weights of materials vandalized by Bland. 


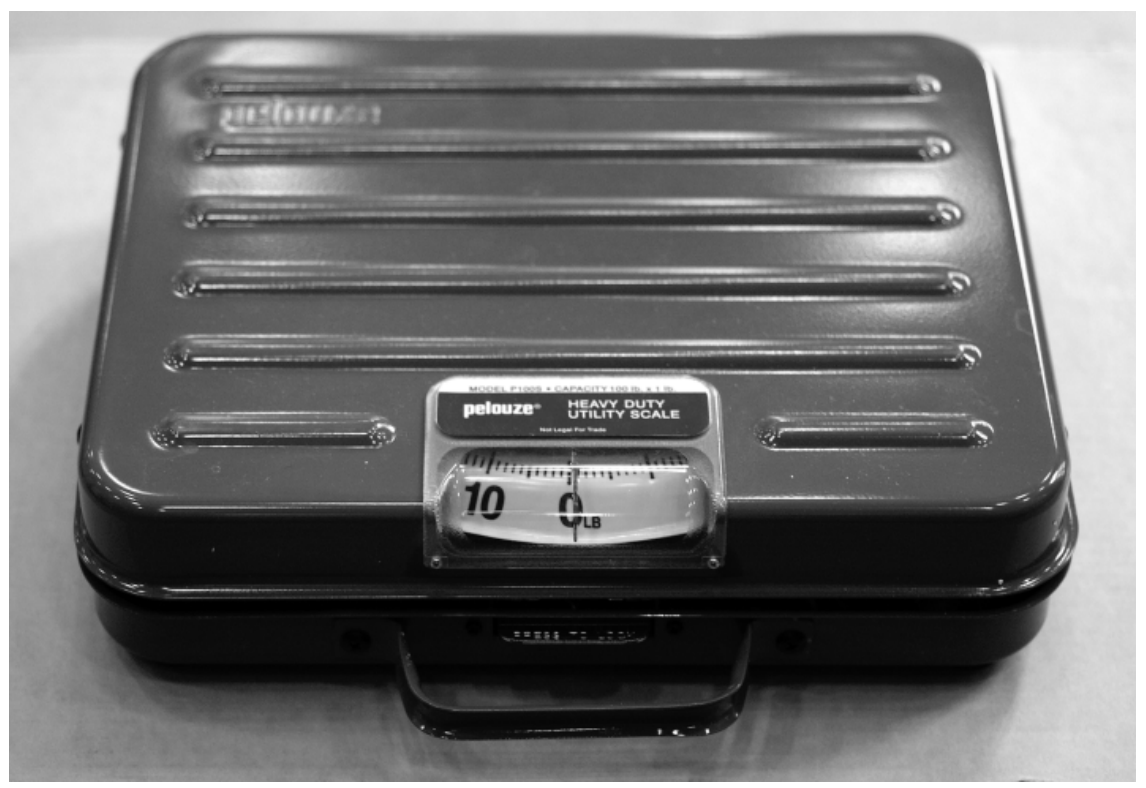

Figure 1. A typical avoirdupois postal/shipping scale that will weigh up to $100 \mathrm{lb}$. Note that the increments are too coarse, however, to be of significant use for security. Photo by Michael L. Taylor, Lilly Library, Indiana University. Used by permission.

for such scales, they are used widely for weighing postage or calculating shipping charges. In general, postal scales will weigh to 0.00 ounce, the only practical standard they need to meet in everyday use. On the other hand, they will readily weigh fairly heavy items. Even the simplest postal scale will weigh items up to ten pounds. More sophisticated avoirdupois scales, meant for scientific or industrial use, can weigh down to 0.005 pound (2.27 gm) or even to 0.001 pound ( $0.45 \mathrm{gm}$ ). (See Figure 1.)

The chief drawback of an avoirdupois postal scale is that its default setting is so high it fails to weigh at a precise enough interval, as compared to a metric scale. Because it needs to weigh only in whole ounces to be useful, it will actually detect small weights, such as a tissue sheet, but will not reflect the actual weight to a precise degree. Such simple scales should probably be avoided despite their attractive price. Because a metric scale weighing in grams will reflect discrepancies with a larger number than an avoirdupois scale, the former is recommended. A gram is a far smaller unit of measure than a pound or even an ounce, and scales measuring that type of weight will perforce reflect larger readings than those weighing avoirdupois, thereby increasing the likelihood of detection.

In selecting a scale, one should be careful to choose one that is capable of detecting the desired weights but yet not overly sensitive. A scale that will weigh $1200 \mathrm{gm}$ (about $2 \mathrm{lb} 10 \mathrm{oz}$ ) at 0.000 is about at the upper level of sensitivity for the weight 
such a scale will hold. A less sensitive scale that will weigh 8200 (about $18 \mathrm{lb} 1 \mathrm{oz}$ ) grams will generally weigh only to a sensitivity of 0.0 gram or one whole gram (see figures 2 and 3 ).

In weighing manuscript folders and most books, a scale that weighs in the hundredths of a gram (0.00) up to $4500 \mathrm{gm}$ (about $10 \mathrm{lb}$ ) should be adequate; one less sensitive may prove inadequate because it will not be able to detect the removal of small pieces of material, such as a signature from a letter or a bookplate. For larger bound volumes, the situation is somewhat equivalent. If a book weighs 8000 gm (about $17 \mathrm{lb}$ ), the most sensitive metric scale available will probably weigh at the $0.0 \mathrm{gm}$ level. That level of sensitivity, however, would probably be sufficient

\begin{tabular}{|c|c|c|c|c|c|c|}
\hline \multicolumn{7}{|c|}{$\begin{array}{l}\text { FIGURE } 2 \\
\text { Generic Example of Full Specification Sheet For Metric Scales }\end{array}$} \\
\hline \multicolumn{7}{|c|}{ Portable Scale Specifications } \\
\hline & $\# 1$ & $\# 2$ & $\# 3$ & $\# 4$ & $\# 5$ & \#6 \\
\hline Maximum capacity & $150 \mathrm{~g}$ & $300 \mathrm{~g}$ & $600 \mathrm{~g}$ & $600 \mathrm{~g}$ & $1500 \mathrm{~g}$ & $3000 \mathrm{~g}$ \\
\hline Minimum capacity & - & - & - & - & - & - \\
\hline Readability & $0.005 \mathrm{~g}$ & $0.01 \mathrm{~g}$ & $0.02 \mathrm{~g}$ & $0.01 \mathrm{~g}$ & $0.05 \mathrm{~g}$ & $0.1 \mathrm{~g}$ \\
\hline Tare range & Full & Full & Full & Full & Full & Full \\
\hline Repeatability & $0.005 \mathrm{~g}$ & $0.01 \mathrm{~g}$ & $0.02 \mathrm{~g}$ & $0.01 \mathrm{~g}$ & $0.05 \mathrm{~g}$ & $0.1 \mathrm{~g}$ \\
\hline Linearity & $0.01 \mathrm{~g}$ & $0.02 \mathrm{~g}$ & $0.04 \mathrm{~g}$ & $0.02 \mathrm{~g}$ & $0.1 \mathrm{~g}$ & $0.2 \mathrm{~g}$ \\
\hline Stabilization time & 3 secs & 3 secs & 3 secs & 3 secs & 3 secs & 3 secs \\
\hline Units of measure & \multicolumn{6}{|c|}{$\begin{array}{l}\text { gram, hundredweight, pound, ounce, dram, pennyweight, } \\
\text { carat, grain }\end{array}$} \\
\hline Interface & \multicolumn{6}{|c|}{ RS-232 (1200-9600 baud rate) } \\
\hline Operating temperature & \multicolumn{6}{|c|}{$0^{\circ} \mathrm{C}-40^{\circ} \mathrm{C}$} \\
\hline Power supply & \multicolumn{6}{|c|}{$\begin{array}{l}\text { AC power } 120 \mathrm{VAC} \text { or } 230 \mathrm{VAC}, 9 \mathrm{~V} \text { adapter, or } 4 \text { dry cell } \mathrm{C} \text { bat- } \\
\text { teries }\end{array}$} \\
\hline Calibration & \multicolumn{6}{|c|}{ Automatic external calibration from keypad } \\
\hline Display & \multicolumn{6}{|c|}{ Backlit LCD $95 \mathrm{~mm} \times 25 \mathrm{~mm}$} \\
\hline Draft shield & Yes & Yes & Yes & Yes & Yes & Yes \\
\hline - Details & \multicolumn{6}{|c|}{ Plastic windshield standard } \\
\hline - Dimensions & \multicolumn{6}{|c|}{$155 \times 137 \times 80 \mathrm{~mm}$} \\
\hline Pan size & \multicolumn{4}{|c|}{$116 \mathrm{~mm} \varnothing / 4.6 " \varnothing$} & \multicolumn{2}{|c|}{$\begin{array}{l}144 \times 124 \mathrm{~mm} / \\
5.7 \times 4.9^{\prime \prime}\end{array}$} \\
\hline Overall dimensions & \multicolumn{6}{|c|}{$175 \times 226 \times 63 \mathrm{~mm} / 6.9 \times 8.9 \times 2.5^{\prime \prime}$} \\
\hline Gross weight & \multicolumn{6}{|c|}{$2 \mathrm{~kg} / 4.4 \mathrm{lb}$} \\
\hline Functions & \multicolumn{6}{|c|}{ Weighing, Parts Counting, \% Weighing } \\
\hline Other features & \multicolumn{6}{|c|}{$\begin{array}{l}\text { Auto power off. All functions can be enabled/disabled and } \\
\text { initial functions can be set. }\end{array}$} \\
\hline
\end{tabular}


to detect removal of any individual leaves, bearing in mind that such items as atlases have relatively heavy leaves. If one acquires a very robust metric scale that will weigh objects up to $10,000 \mathrm{gm}$ (about $22 \mathrm{lb}$ ), the sensitivity will generally again fall to $1 \mathrm{gm}$. It may be desirable to acquire two scales of different capacities, one for small items and another for larger items. ${ }^{4}$

Some scales are equipped with weighing options that the operator may choose. A scale may be made to weigh in ounces, grams, grains, carats, or any other of a number of weighing schemes if it is ordered with the proper programming. In considering which features to purchase, the institution may find various weighing capacities of interest. If, for example, one has historic gunpowder samples, a scale that can weigh in grains, the standard for such a material, may be desirable. If a collection contains many very small, lightweight items, a finer tolerance than a gram might also be desirable in such a situation. Before selecting a scale, the institution needs to give some thought to the variety of material it owns and what might be called to the reading room.

\begin{tabular}{|l|c|}
\hline \multicolumn{2}{|c|}{ FIGURE 3} \\
$\begin{array}{c}\text { Examples of Capacities for Metric Scales } \\
\text { Showing Accommodated Maximum } \\
\text { Weights and Relative Sensitivities }\end{array}$ \\
\hline $\begin{array}{c}\text { Maximum capacity } \\
\text { (grams } / \text { pounds })\end{array}$ & Sensitivity \\
\hline $150 \mathrm{~g}(.330 \mathrm{lb})$ & $0.001 \mathrm{~g}$ \\
\hline $150 \mathrm{~g}(.330 \mathrm{lb})$ & $0.005 \mathrm{~g}$ \\
\hline $210 \mathrm{~g}(.462 \mathrm{lb})$ & $0.01 \mathrm{~g}$ \\
\hline $300 \mathrm{~g}(.660 \mathrm{lb})$ & $0.01 \mathrm{~g}$ \\
\hline $310 \mathrm{~g}(.683 \mathrm{lb})$ & $0.001 \mathrm{~g}$ \\
\hline $410 \mathrm{~g}(.903 \mathrm{lb})$ & $0.01 \mathrm{~g}$ \\
\hline $410 \mathrm{~g}(.903 \mathrm{lb})$ & $0.001 \mathrm{~g}$ \\
\hline $600 \mathrm{~g}(1.32 \mathrm{lb})$ & $0.02 \mathrm{~g}$ \\
\hline $600 \mathrm{~g}(1.32 \mathrm{lb})$ & $0.01 \mathrm{~g}$ \\
\hline $610 \mathrm{~g}(1.34 \mathrm{lb})$ & $0.01 \mathrm{~g}$ \\
\hline $610 \mathrm{~g}(1.34 \mathrm{lb})$ & $0.1 \mathrm{~g}$ \\
\hline $1500 \mathrm{~g}(3.30 \mathrm{lb})$ & $0.01 \mathrm{~g}$ \\
\hline $1500 \mathrm{~g}(3.30 \mathrm{lb})$ & $0.05 \mathrm{~g}$ \\
\hline $2100 \mathrm{~g}(4.62 \mathrm{lb})$ & $0.1 \mathrm{~g}$ \\
\hline $3000 \mathrm{~g}(6.61 \mathrm{lb})$ & $0.1 \mathrm{~g}$ \\
\hline $3100 \mathrm{~g}(6.83 \mathrm{lb})$ & $0.01 \mathrm{~g}$ \\
\hline $4100 \mathrm{~g}(9.03 \mathrm{lb})$ & $0.1 \mathrm{~g}$ \\
\hline $6100 \mathrm{~g}(13.44 \mathrm{lb})$ & $0.1 \mathrm{~g}$ \\
\hline $4100 \mathrm{~g}(9.03 \mathrm{lb})$ & $1 \mathrm{~g}$ \\
\hline $4100 \mathrm{~g}(9.03 \mathrm{lb})$ & $0.01 \mathrm{~g}$ \\
\hline $6100 \mathrm{~g}(13.44 \mathrm{lb})$ & $1 \mathrm{~g})$ \\
\hline $12,000 \mathrm{~g}(26.45 \mathrm{lb})$ & close or identi- \\
\hline $\begin{array}{l}\text { Note that scales can vary in sensitivity even } \\
\text { when maximum weights are } \\
\text { dal. (Extracted and condensed from several }\end{array}$ \\
\hline
\end{tabular}

Several other considerations also influence one's choice of a scale. Any scale appropriate for weighing books and manuscripts must have an unobstructed flat weighing surface (sometimes called a "pan" or "platform") of adequate size to hold most materials. To produce an accurate weight, it is not necessary that the object being weighed fit entirely on the pan, only that it rest solidly upon it; overhang

4. If the capacity of a scale is exceeded, it will display an error code. It is important to know at which point this code will be displayed. On some scales, it is at about $102 \%$ of capacity; on others, it can be as much as $150 \%$ of capacity. 


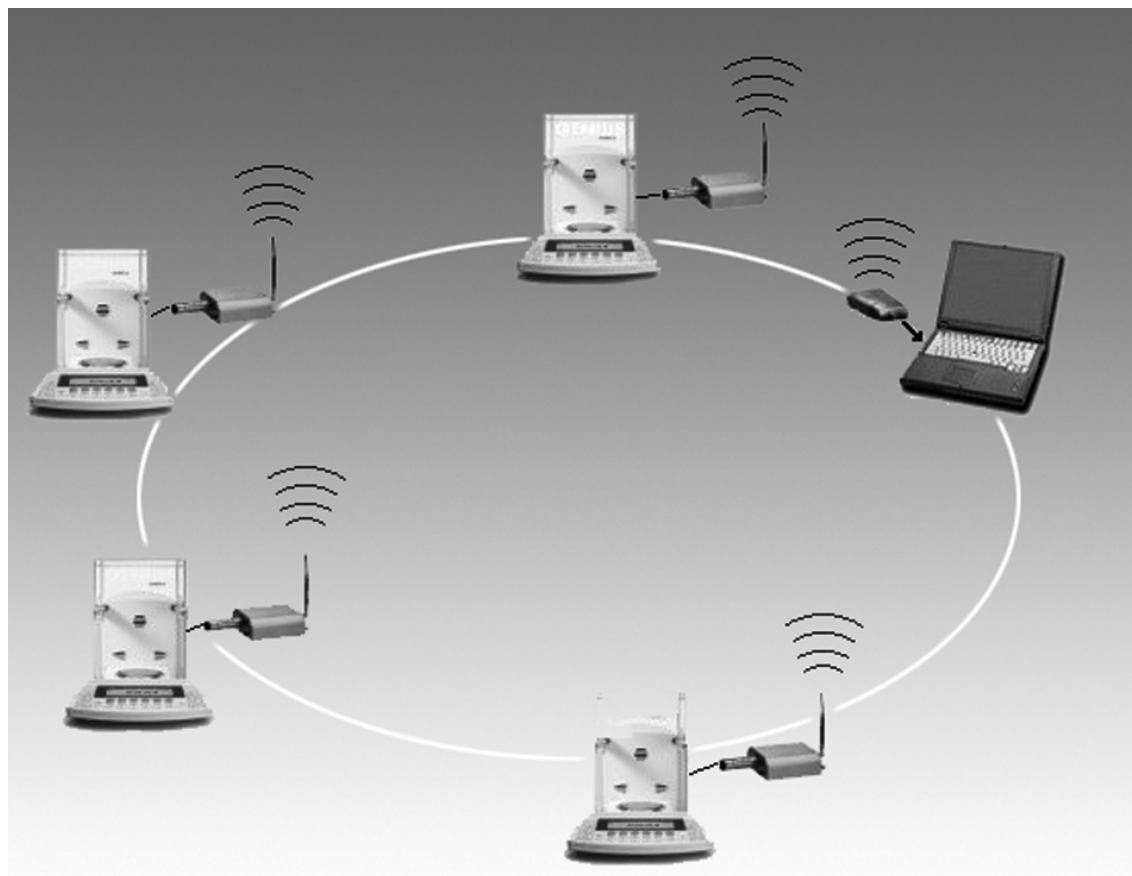

Figure 4. Schematic of a network of scales using Blue Tooth $^{\circ}$ to communicate weights to a remote computer/device. Photo Courtesy of Sartorius Corporation.

is acceptable (see below). The pan should be square rather than round. Also, the scale must have some easy way to be calibrated either manually or electronically. To work accurately, the scale needs to be level on a sturdy, flat surface, and special tables are available for that purpose. For ease of leveling, some scales are equipped with a floating ball and adjustable legs. The readout screen will undoubtedly be digital. Another feature common in modern scales is an RSC 232 interface for exporting data to a computer or other device; software is available to automate the export function (see figure 4). In most instances, this interface should be chosen as an option even if there are no immediate plans for its use so as to have the capability of sending weighing data to a computer at some point in the future. Most scales can use a $120 \mathrm{~V}$ or $230 \mathrm{~V}$ power supply, preferably conditioned, and many are also equipped with batteries. Because features of scales often cannot be easily altered or upgraded after manufacture, it is important to consider carefully which features the library will need before buying the device.

\section{Security Applications}

In practice, the intention is that all materials will be weighed before they are issued to a reader and then reweighed when returned (see figures 5-8). Any meaningful discrepancy in the two weights should be cause for concern. As can be seen from Appendix 1, any discrepancy shown by a gram scale will probably be large enough 
to detect, even if only a single leaf has been removed. The larger the proportion of materials removed, the greater the discrepancy will be. This is an important consideration for materials such as large atlases or volumes containing plates, which are often the targets of vandalism. The leaves comprising such volumes are relatively heavy; in fact, to

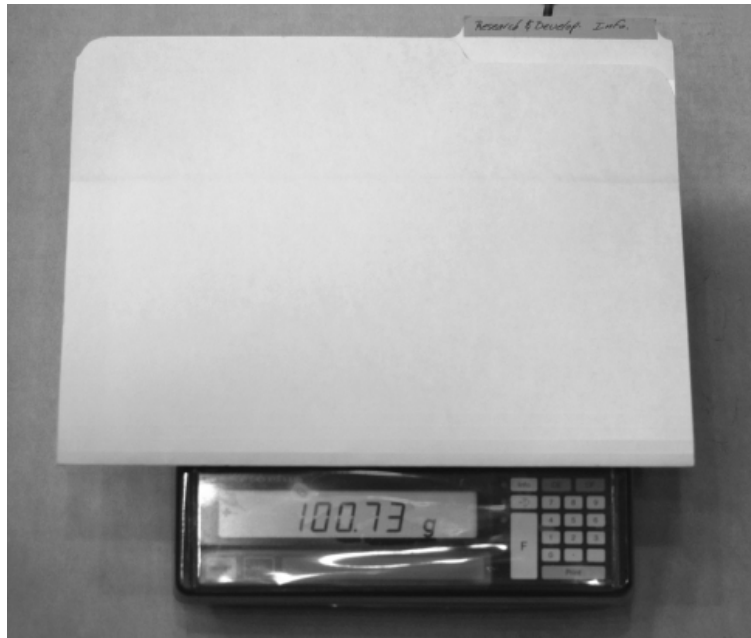

Figure 5. A letter-size folder of modern typescripts. Courtesy of the Lilly Library, Indiana University.

a metric scale weighing

at even one gram, they are huge. The removal of even one of them will result in a large weight discrepancy. (See Appendix 2.)

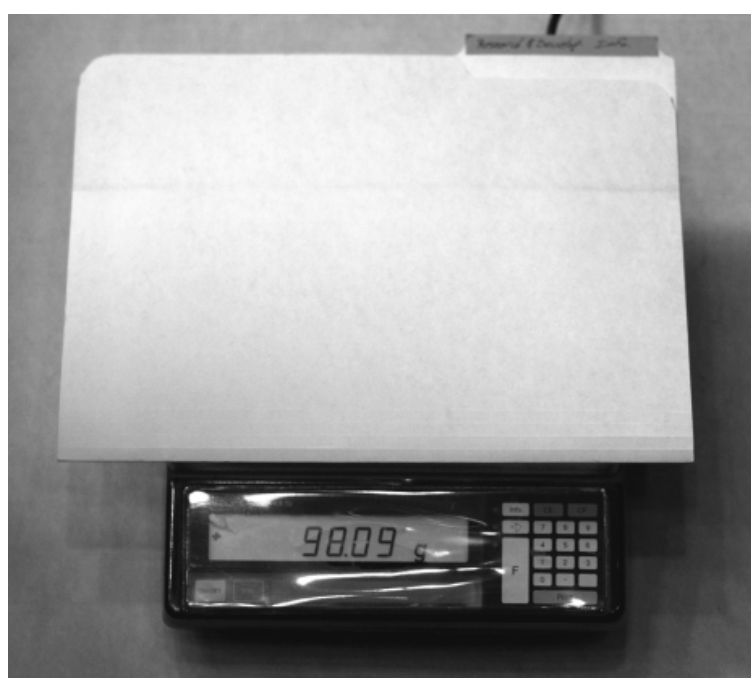

Figure 6. The same letter-size folder of modern typescripts with one removed. Note the reduced weight. Courtesy of the Lilly Library, Indiana University.
The chief theoretical problem with this system is that a thief will substitute something for what has been removed. ${ }^{5}$ Because of repeated experiments the author did using various types of materials, it seems highly unlikely that a thief could accomplish this feat. Especially with older books, the weighing system will probably always defeat the practice of substituting one entire volume for

5. This type of behavior was engaged in by a still unidentified thief at the Library Company of Philadelphia in the 1970s. The library's book was eventually recovered from a bookseller. [Based on interviews with Library Company of Philadelphia staff.] Modern books present more problems because they are basically identical. If one had a small pamphlet of poetry printed in 1996 and signed by the author, and a thief substituted an otherwise identical but unsigned copy, the scale probably would not detect the substitution. 
another because it is nearly impossible to match the weight of the substituted volume accurately with the weight of the stolen one. Even such features as bookplates and missing pieces of leather on the binding will produce significant weight variances. Attempting to substitute leaves of

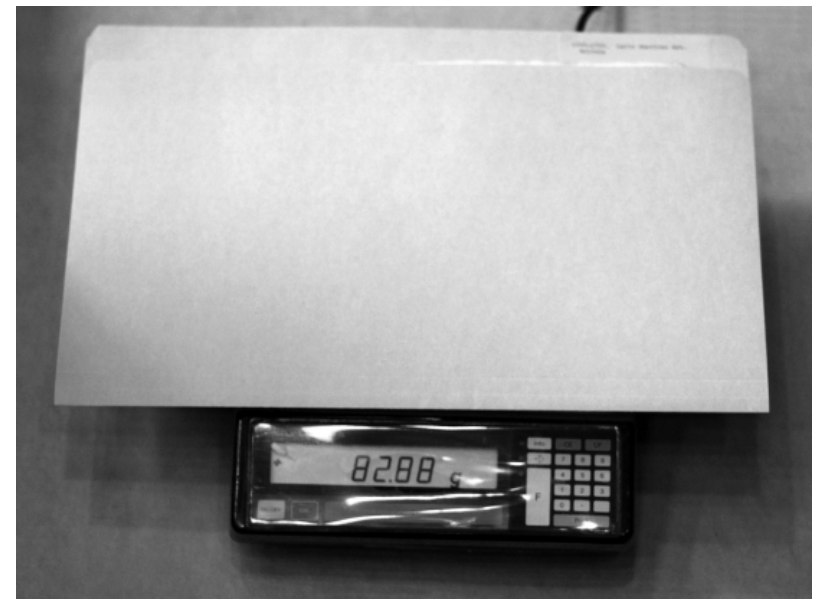

Figure 7. A legal-size folder of seventeenth-century manuscripts. Courtesy of the Lilly Library, Indiana University.

equivalent weight to

the ones removed is also exceedingly difficult to accomplish. For such a procedure to work successfully, the thief would need to know accurately what the removed leaf weighed so that a proper substitute could be at hand, a number virtually impossible to divine in advance. The most vulnerable collections to such swapping procedures seem to be modern manuscripts. If they are recent enough, it is possible to obtain paper that is nearly identical to what is to be stolen, substitute it, and not alter the weight of a folder significantly. Even that possibility, however, has proven remote in experiments.

Weighing materials also has potentially significant applications in internal security.

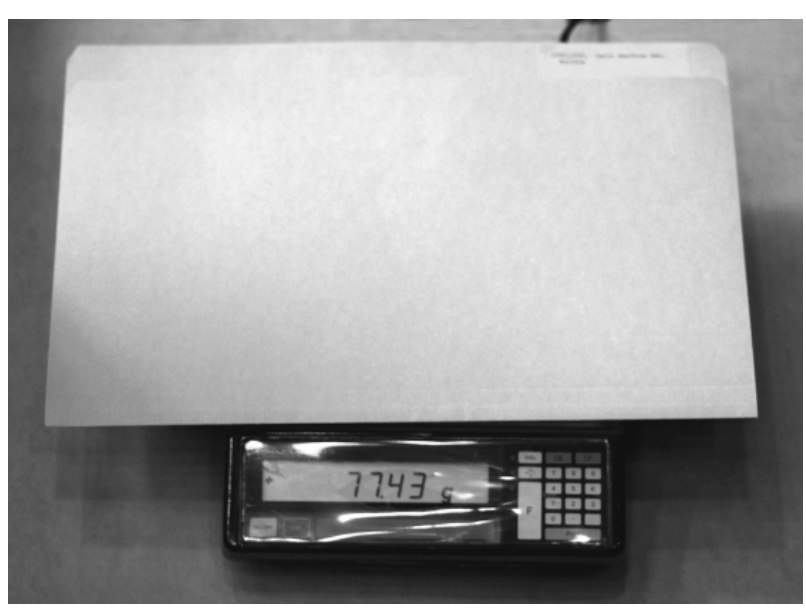

Figure 8. The same legal-size folder of seventeenth-century manuscripts with one removed. Note the reduced weight. Courtesy of the Lilly Library, Indiana University.
One could weigh books as they are accessioned if they are to be added to a backlog, thereby establishing a baseline measurement that would be valid until the item is actually catalogued. Any later discrepancy in the weight, especially if an item had not circulated, should give rise to suspicions 
of insider theft. ${ }^{6}$ The procedure also has applications when collections are moved. Items could be weighed before they were moved and then weighed again when reshelved in their new location. Again, any significant discrepancy would be cause for concern. ${ }^{7}$ In situations where large amounts of unprocessed manuscripts are accessioned, an institution would clearly need to wait until a final arrangement had been accomplished before weighing the individual cartons or boxes for this purpose. Even if, however, a researcher were given access to unprocessed materials, the weighing system would still be effective if unprocessed items were weighed at the time of issue. Of course, recorded weights would need to be kept current. If an item is sent for conservation, for example, any such procedures are probably going to alter its weight in a meaningful way.

If weighing procedures are instituted, a major consideration is going to be whether patrons know the process is being applied to materials they are using. One school holds that security measures should be obvious and blatant, as is clear in any bank with cameras dangling from every wall. Under such a philosophy, the method would be to weigh the item right in front of the user and make no bones about why it is being done. This procedure would seem to be the one with the greater deterrent value. ${ }^{8}$ Another school holds that security measures should generally be covert and opaque. In that case, the items would probably be weighed outside the view of the user, who would remain none the wiser. This procedure would seem to hold more promise for catching an actual thief, although the damage may have already been done. In either case, the patron should never be told the weight. Because of the possibility of false identification, whichever method is chosen, a suspected thief should never be allowed to leave the premises until a meaningful discrepancy is resolved. It is possible a patron is not who $\mathrm{s} /$ he appears to be. Another consideration, especially in the U.S., is that there should be nobody with intervening custody of materials between the patron and the person who does the actual weighing. That consideration also mitigates against weighing

6. For a discussion of insider theft and its consequences, see Daniel Traister, "Seduction and Betrayal: An Insider's View of Insider Theft of Rare Materials," Wilson Library Bulletin, 69 (September 1994): 30-33 and Ton Cremers, "Rogues Gallery: An Investigation into Art Theft ... and the Curator Did It" (www.museum-security.org/insider-theft.pdf). Insider theft is all too common, the most recent incident uncovered being that of volunteer Mimi Meyer at the Harry Ransom Humanities Research Center at the University of Texas, Austin, whose case is summarized by Mark Lisheron in "Book Bandit Rocked Ransom," Austin American-Statesman (1 February 2004). For press releases on other solved insider thefts, see http:/ / palimpsest.stanford.edu/byform/mailing-lists/ exlibris/1995/12/msg00101.html and http:/ / palimpsest.stanford.edu/byform/mailing-lists/exlibris/1998/07/msg00115.html. Obviously, no weighing program will be effective against a staff member who surreptitiously removes entire volumes, as Meyer did.

7. This situation arose recently at Yale University when a student worker hired to shift materials stole some items from the collections while they were being moved. See William Kaempffer and Natatie Missakian, "\$2 Million Heist: Hamden Man Suspected in Yale theft," New Haven Register (30 November 2001).

8. In the one library that reports that it weighs items in plain sight of patrons, the curator states that many patrons seem oblivious to the procedure and do not seem to realize what is happening. 


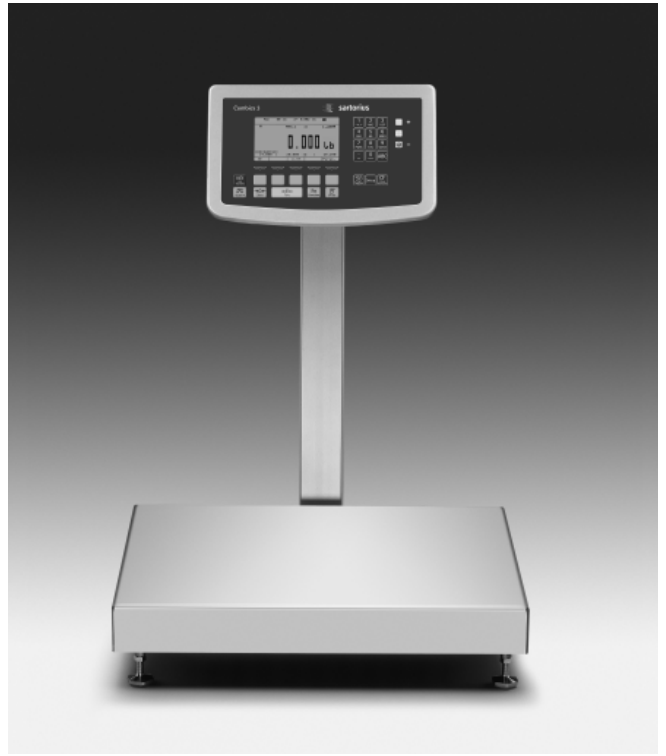

Figure 9. One type of scale with the readout mounted on an arm. Photo courtesy of Sartorius Corporation. items later after a patron has

already left. ${ }^{9}$

\section{Practical Issues}

Implementation of a security weighing system involves a learning curve for those involved with its use. As with any security application, not everything is going to be perfect or problem-free. Just as with something like a CCTV surveillance system, the institution will have to balance alternatives to decide if a weighing program is appropriate. Common concerns likely to arise are these:

1) Humidity. Because almost all rare book and manuscript libraries have climate control in both their stacks and reading rooms, weight variations introduced by relative humidity are generally unimportant. Even for those without such controls, it is also rarely an issue. Items are weighed at the moment they are issued, and the environment is unlikely to affect them in any meaningful way while they are being used. Even a volume brought from a dry environment into a humidified, climate-controlled environment will not quickly absorb a significant amount of water from the atmosphere. In fact, it requires days or even weeks for a volume to absorb or lose all the humidity it can hold. In general, concerns about weight changes caused by water loss or absorption are of little concern in this context. ${ }^{10}$

9. "Chain of custody" is a significant legal concept in this instance. If, for example, Patron X turns a book into Librarian A, who then passes it on to Librarian B, who then passes it on to Librarian C, who actually weighs the book, it could be argued that any missing material might have been removed by Librarians B or C. It is important, therefore, that Librarian A, who takes immediate possession of the book from the patron, do the actual weighing on the spot. In the case of John Hajicek, falsely arrested for supposedly stealing books from a library, he was completely exonerated when he demonstrated that some of the evidence against him could not possibly have been seized at the time of his arrest, a classic case of breaking the chain of custody. See Columbia (MO) Daily Tribune, 22 April 1995 (http:/ / archive. columbiatribune.com/1995/apr/19950422news13.htm) and 24 April 1995 (http:/ / archive.columbiatribune.com/1995/apr/19950425news16.htm).

10. Conclusion based upon phone conversations with staff of the Image Permanence Institute in 2004. Such considerations will be of concern, however, if items are weighed when accessioned. Because they might well either lose or absorb moisture in the first few weeks after they are brought into the library, an accurate weight might have to wait for several weeks to allow for this process. 


\section{2) Weight Discrepan-}

cies. Because scales are sensitive, it is possible that there will be weight discrepancies that are not meaningful. In general, a small weight discrepancy to the right of the decimal point will prove to be meaningless in the average book or manuscript folder. Only those to the left of it will matter. Thus, if an item weighs 225.20 gm when issued and, upon return, weighs $225.10 \mathrm{gm}$, the difference is probably negligible. If upon return it weighed 220.00 gm, however,

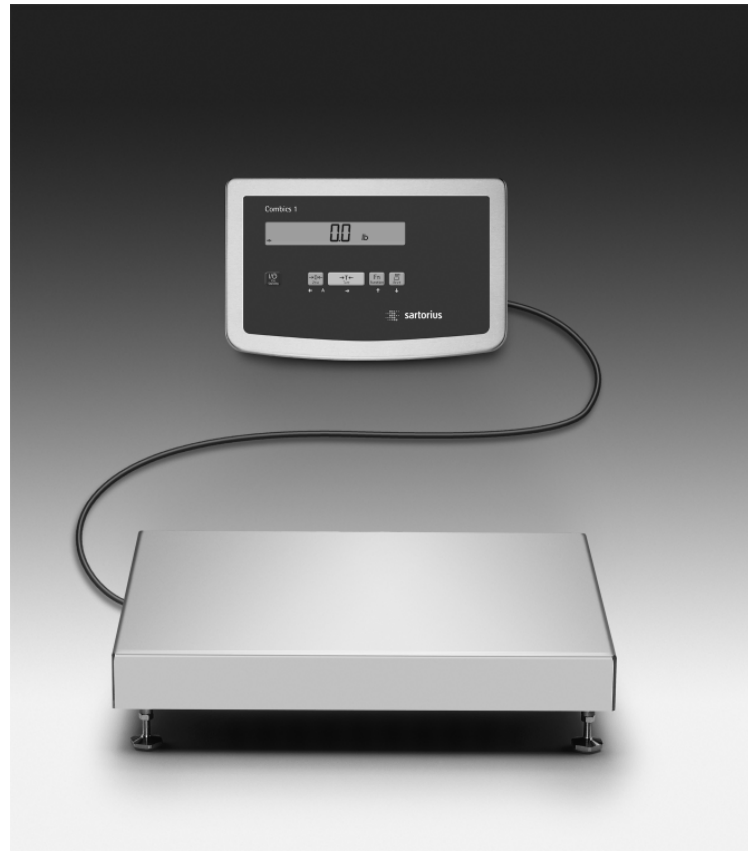

Figure 10. A scale with a remote readout attached by a cable. Photo courtesy of Sartorius Corporation.

that would be cause for

concern. It should be noted that any significant increase in weight is also cause for concern because it may indicate something has been substituted for something removed or even that something has been added. ${ }^{11}$

Care should also be taken to ensure that the object when weighed is exactly in the form that is issued to the patron. If such items as duplicate copies of call slips or call flags are issued with the item, they should probably be removed before the item is weighed so that the weight shown is for the item only. In other cases, extra-

11. John Cockett (aka John Drewe) planted documents in library archival collections, thereby creating false provenance, to make it appear that objects he was selling were genuine. See Jennifer Booth, "Dr. Drewe-A Cautionary Tale," Art Libraries Journal, 28: 2 (2003): 14-17; and Beth Houghton, "Art Libraries as a Source of False Provenance," World Library and Information Congress: 69th IFLA General Conference and Council, 1-9 August 2003, Berlin (www.ifla.org/IV/ifla69/papers/047e-Houghton.pdf). It was conjectured in some quarters that Samuel Berger, who admitted removing documents from the National Archives in 2003, may have also substituted forgeries favorable to President Clinton. See, for example, www.captainsquartersblog.com/mt/archives/cat_trousergate.php. For a summary of the Berger controversy, see John F. Harris and Susan Schmidt, "Archives Staff Was Suspicious of Berger: Why Documents Were Missing Is Disputed," Washington Post (22 July 2004). In some quarters, the competence of the archivists was questioned, on which see, for example, Fred Kaplan, "Berger with a Side of Secret Documents: Is He a Criminal or a Klutz?” (21 July 2004), online at http://slate.msn.com/id/2104138. Special leaves are sometimes removed from otherwise ordinary books. At Yale University in 2005 a thief removed from a book a leaf inscribed and dated by Arthur Conan Doyle (see http://palimpsest. stanford.edu/byform/mailing-lists/exlibris/2005/03/msg00190.html). 
neous materials are sometimes deliberately introduced into collections. A common example of that practice is the use of some type of flag or marker to indicate in manuscript boxes which items are to be photocopied. It would be preferable if photocopy requests could be made without inserting anything extra into a container, but if that is not possible, then all the flags need to be utterly identical so that their extra weight can be accurately accounted for when the box is returned. Introducing such extraneous materials into weighed materials, however, unnecessarily muddies the waters and should be avoided.

3) Pan Size. Most scales have a pan large enough to accommodate the majority of books and manuscript folders. For an accurate weight, it is required only that they rest squarely on the pan; orientation on the pan is not a factor. Occasionally, it is possible to encounter a situation in which the item to be weighed is of large size or of such a format that it does not fit on the pan properly. A folio volume of prints still in its original paper wrappers is an example of such a problem; it may be so limp that it will not rest correctly on the pan. In such cases, one may use a piece of stiff material, such as binding board, to support the object. One would first weigh the board separately and record its weight, referred to as the tare. Then one would place the object on the board, which would support it, and calculate the object's

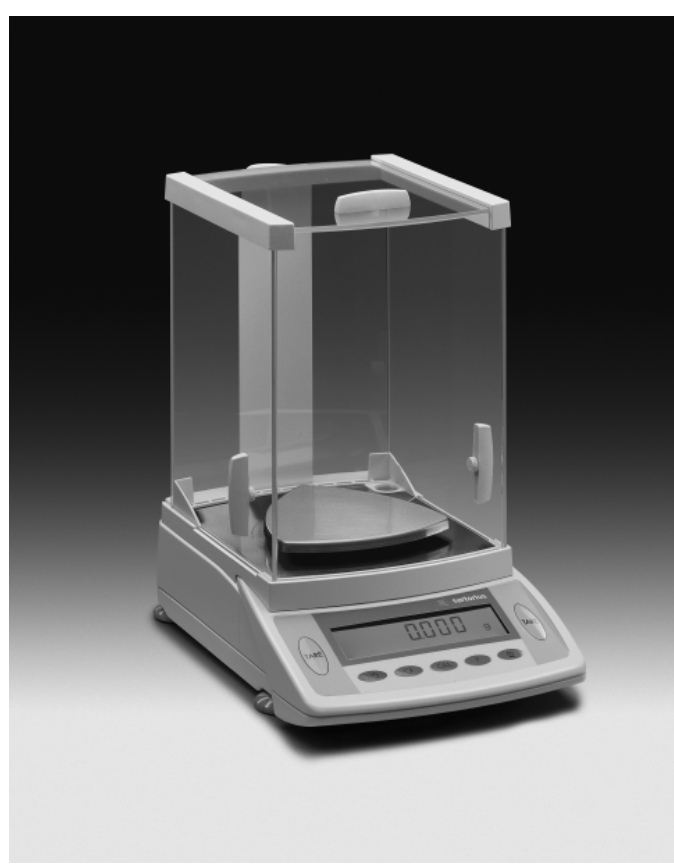

Figure 11. Example of a scale with a hood or draft shield. This particular configuration is an example only; this type of hood is inappropriate for most security applications in a reading room unless one is weighing small, delicate objects. weight by subtracting the tare weight. Most scales automate this function and automatically subtract the tare from the weight once the tare is entered. Because some large objects can obscure the readout on small scales, it might be desirable to obtain one with the readout mounted on an arm or one with a remote readout (see figures 9 and 10).

4) Installation. All scales are subject to various forces that alter the apparent weight of objects. Some of those are entirely undetectable to human senses but will be detected by the scale. Two forces especially will act negatively on a scale's accuracy. The first 
is vibration. The unit should, therefore, be located where it is not subject to interference from such things as machinery or passing subway cars. If needed, special tables, which are large, heavy objects (ca. $350 \mathrm{lb}$ ) usually made of epoxy resin, are available. For more severe cases, vibration damping mounts can be acquired. The second force is the movement of air on the pan. The scale should be located where it is not subject to air rushing from HVAC vents or fans onto the pan, as such a situation will cause the readout to fluctuate

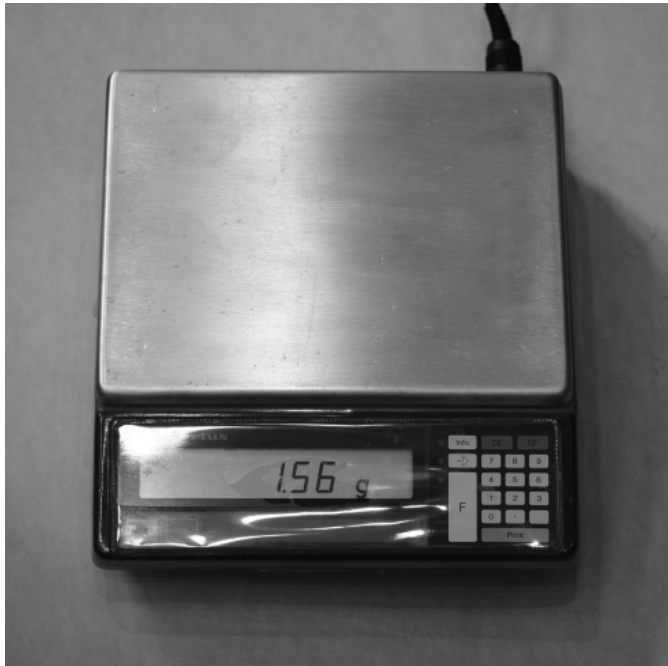

Figure 12. A portable scale with built-in readout. Note the reading, which is caused by air movement on the otherwise empty pan. Photo by Michael L. Taylor, Lilly Library, Indiana University. Used by permission. and compromise weighing accuracy. One may easily arrive at an appreciation of this problem merely by blowing on the pan and witnessing the effect of air turbulence on the readout. If necessary, the entire unit can be enclosed in a clear hood to insulate it from such effects. ${ }^{12}$ In any case, the scale must be installed so that the readout is stable and reads 0 when the pan is empty (see figures 11 and 12).

5) What to Weigh? Probably not everything needs to be weighed before it is issued. Low-value items such as modern reference books might be exempt from the procedure in most institutions. Single-sheet items, such as broadsides or separate maps, might also be exempt since any damage to them would be obvious. Any time, however, that a photocopy request is denied, the item, without regard to its value, should be weighed before being returned to the patron, who may decide to remove the needed leaves rather than undergo the onus of transcribing the information. ${ }^{13}$

A rare but real problem is the substitution of extremely expert facsimiles for original materials, a situation that would most probably occur with broadsides, maps, or other single-sheet materials. Such considerations may induce a library to weigh

12. If one selects a scale to weigh very fine increments, such as grains, it will be vital to provide a hood to insulate the pan from air movements. Appropriate hoods can be fabricated by many firms, including museum exhibition companies.

13. The author has personal knowledge of several such incidents. 
such items; it is difficult, however, to duplicate accurately an original's weight with a facsimile, no matter how excellent the reproduction. ${ }^{14}$ (See footnote 2.)

6) Maintenance. Modern scales are robust, designed for extended use, and require little maintenance. The one routine maintenance procedure they will require, however, is calibration to ensure that they remain accurate. Normally calibration is a simple procedure requiring no special training or equipment and is done in accordance with the manufacturer's recommendation. Proper instrument maintenance and calibration do, however, have some legal implications, and attention to them is necessary. Maintenance contracts for the devices should probably also be procured.

7) Procedural Considerations. Using a scale to weigh materials may involve some procedural changes, especially in regard to manuscript collections. The practice of allowing researchers to have entire book trucks of manuscripts in the reading room would easily defeat the purpose of weighing materials. A scale large enough to weigh such a mass would be so insensitive that it would not detect the removal of single items. If researchers were issued only boxes or folders, however, that were weighed when issued, the scale could probably detect the removal of even something like a small sticky note or signature if the scale weighed at $0.00 \mathrm{gm}$.

8) The Problem of "When?” A vexing problem involving theft of leaves from books, such as individual maps or plates, is determining when the removal actually happened. If, for example, an atlas is discovered to be missing a map after being used by Mr. X, suspicion naturally falls on him immediately. The alternate possibility, however, is that the map was already gone when the volume was issued to Mr. X. Because almost no library collates material every time it is used, staff often cannot absolutely be certain that the map was there when Mr. X called it to the reading room and used it. If the item were weighed before being issued, however, the matter would be clearer. If the map were already missing, that lack would be reflected in the initial weight. Weighing materials also has implications, therefore, in protecting innocent researchers who just happen to be in the wrong place at the wrong time.

14. This is a situation that could be avoided almost entirely by an adequate marking program. (For current marking guidelines, see ACRL/RBMS, Guidelines, Appendix I.) A plague of expertly (and notso-expertly) forged documents was unleashed on the Texana market several years ago. For a discussion of the history of those documents, see W. Thomas Taylor, Texfake: An Account of the Theft and Forgery of Early Texas Printed Documents (Austin: W. Thomas Taylor, 1991). The general problems of forgeries and both library and booksellers' reactions to the problems they cause are discussed in Pat Bozeman, ed., Forged Documents: Proceedings of the 1989 Houston Conference (New Castle: Oak Knoll, 1990), wherein Jennifer Larson, "Obligations of the Dealer: The U. S. Perspective," reports that forger Mark Hoffman in one case substituted a forgery and stole the genuine item at an unnamed library (p. 137). The Folger Shakespeare Library holds several copies of genuine early broadsides and another copy thought to be an expert facsimile of one of them; it, however, refused to allow me to weigh them. 
9) What If? Implementing a weighing program is something like buying a firearm for personal protection. One must be willing to use it. Not only must the library regularly weigh all appropriate items issued to readers, but also it must have the will to act upon the results. If a library is not willing to confront a reader who seems to have damaged or stolen library materials, a weighing program will do little good in the end. Some soul searching and the implementation of appropriate procedures should be accomplished before the first item is ever weighed.

\section{Conclusion}

Although the idea of weighing objects to determine damage or loss is a relatively new concept in the field of rare books, manuscripts, and special collections, it has been used with success in other venues. It was common practice, for example, that banks would weigh rolls of coins to ensure that a roll did not contain items such as slugs or washers instead of actual coins, and variations of money- weighing procedures are still in use today at some banks, security companies, and retail operations. ${ }^{15}$ Manufacturers routinely weigh products to ensure quality control. Weighing rare books and manuscripts seems to offer another viable method for preventing thefts and mutilation, although it is admittedly not perfect and should be considered as only one piece of an overall security program.

Every person with custody of rare and valuable materials wishes for a Holy Grail or Magic Bullet of security that will detect every instance of theft and vandalism. No such system has ever been invented, however, so adequate security depends on the use of many methods, each of which is designed to detect only certain acts. As one correspondent, who must remain anonymous, once told me: "I retain a healthy respect for the determined, capable, professional thief or fraudster, who I believe could probably circumnavigate our systems, but we have a duty to make life as difficult as possible for him, and to deter the opportunist as well." ${ }^{\prime 16}$ We must all agree with that sentiment and the caution expressed therein. In the movie Harry Potter and the Prisoner of Azkhaban, a scene in the Hogwarts library's rare book section reveals that the books were endowed with the power to call for help if anyone tampered with them. Until we discover how so to endow our materials, vigilance and numerous detection methods must remain the arms of our profession. Weighing materials may also find a useful place in our arsenal.

15. That procedure is practicable because in the U.S. coin weights are generally controlled down to the 0.00 gm level. See U.S. Code, Title 31, Subtitle IV, Chapter 51, Subchapter 2, 5112. Scales specifically designed and programmed to weigh money are still available.

16. E-mail to author, 30 September 2005. 


\section{Appendix I \\ Representative Weights}

This table is intended to give users some idea of how much objects actually weigh to guide them in deciding what type of scale might be employed in a given library given the nature of the collections. All avoirdupois weights are approximations arrived at mathematically since no proper avoirdupois scale was available for use at the time this paper was written.

Weights to 0.00 gram and pounds/ounces of some everyday materials

$\begin{array}{lll}\text { Material } & \text { Pounds } & \text { Grams } \\ \text { Photocopy paper (8-1/2" x 11") } & 0.19 \mathrm{oz} & 5.43 \mathrm{gm} \\ 100 \% \text { cotton bond (8-1/2" x 11") } & 0.16 \mathrm{oz} & 4.58 \mathrm{gm} \\ \text { Large Kleenex }{ }^{\circledR} \text { sheet } & 0.04 \mathrm{oz} & 1.37 \mathrm{gm} \\ \text { Credit card } & 0.16 \mathrm{oz} & 4.60 \mathrm{gm} \\ \text { Post-It }^{\circledR} \text { note }(3 " \text { x 3") } & 0.01 \mathrm{oz} & 0.43 \mathrm{gm} \\ \text { Business card } & 0.03 \mathrm{oz} & 0.99 \mathrm{gm}\end{array}$

\section{Weights to 0.00 gram and pounds/ounces of some library materials}

Tom Clancy. The Teeth of the Tiger. NY: Putnam, 2003. 8vo.

$741.85 \mathrm{gm}$ (with dust jacket and bookplate) $(1 \mathrm{lb} 10 \mathrm{oz})$

$740.82 \mathrm{gm}$ (with dust jacket but without bookplate) $(1 \mathrm{lb} 10 \mathrm{oz})$

718.77 gm (without dust jacket or bookplate) (1 lb 9 oz)

Catalogue of the Everett D. Graff Collection. Chicago: Newberry, 1968. 4to.

$1868.19 \mathrm{gm}$ (with dust jacket in Brodart ${ }^{\circledR}$ protector) $(4 \mathrm{lb} 1 \mathrm{oz})$

$1849.00 \mathrm{gm}$ (with dust jacket but without Brodart ${ }^{\circledR}$ protector) $(4 \mathrm{lb} 1 \mathrm{oz})$

1820.13 gm (without dust jacket or Brodart ${ }^{\circledR}$ protector) $(4 \mathrm{lb})$

The Bible School Hymnal. NY \& Chicago: Fullar-Meredith, 1907. 8vo.

$457.30 \mathrm{gm}$ (all leaves present) $(1.00 \mathrm{lb})$

$454.14 \mathrm{gm}$ (one leaf removed) $(1.00 \mathrm{lb})$

Close-Up USA. Washington: National Geographic Society, 1978. Plastic case containing book, 1 large folded map, 15 smaller folded maps, and scale printed on small Mylar sheet.

1915.03 gm (complete) (4 lb $4 \mathrm{oz}$ )

$1905.93 \mathrm{gm}$ (with only scale removed) (4 lb $3 \mathrm{oz}$ ) 
$1854.20 \mathrm{gm}$ ( 1 smaller folded map removed) (4 lb)

$1791.91 \mathrm{gm}$ (2 smaller folded maps removed) (3 lb $15 \mathrm{oz})$

1775.79 gm (large folded map removed) (3 lb $14 \mathrm{oz})$

Bound early 19th-c. manuscript music book (oblong)

$384.97 \mathrm{gm}$ (complete) $(13.57 \mathrm{oz})$

$382.03 \mathrm{gm}$ (one leaf removed) $(13.47 \mathrm{oz})$

$379.15 \mathrm{gm}$ (two leaves removed) $(13.37 \mathrm{oz})$

Collection of pieces of 18th-c. Tapa cloth consisting of: one $5.5 \times 5-3 / 4$ " piece of dyed, patterned cloth; one 6 x 6-1/4" piece of dyed, patterned cloth; one 14-1/2 x 14-3/4" piece of undyed, plain cloth; one 14-1/4 x 14-1/4" piece of undyed, plain cloth; one 13 x 15 " piece of undyed, plain cloth; one $13 \times 37-1 / 2$ " piece of undyed, plain cloth; one 21-1/ 2 × 37 " piece of undyed, plain cloth. In cloth clamshell case with ms letter.

$1817.18 \mathrm{gm} \quad$ (Weight of entire collection) $(4 \mathrm{lb})$

$1811.47 \mathrm{gm} \quad$ (Weight with smallest piece removed) $(4 \mathrm{lb})$

$1812.60 \mathrm{gm} \quad$ (Weight with ms letter removed) $(4 \mathrm{lb})$

\section{Weights to 0.00 gram and pounds/ounces of some heavy library materials}

Webster's New Twentieth-Century Dictionary. New York: Publisher's Guild, 1942. $4989.51 \mathrm{gm}(11.00 \mathrm{lb})$

Harry T. Peters. Currier \& Ives: Printmakers to the American People. Vol. 1. Garden City: Doubleday, Duran, 1929. Buckram binding.

$2676.19 \mathrm{gm}(5 \mathrm{lb} 14 \mathrm{oz})$

Harry T. Peters. Currier \& Ives: Printmakers to the American People. Vol. 2. Garden City: Doubleday, Duran, 1931. In dust jacket with Mylar protector and original publisher's box.

$3628.73 \mathrm{gm}(8.00 \mathrm{lb})$

Atlas (folio) of James Cook \& James King. A Voyage to the Pacific Ocean. London: Strahan, etc., 1785.

$4535.92 \mathrm{gm}(10.00 \mathrm{lb})$

Gutenberg Bibles (B42)

Pierpont Morgan Library copies

(Reported in Christopher DeHamel, The Book: A History of the Bible [New York: Phaidon, 2001], p. 207n.)

On paper in 19-c. binding:

ca. $30 \mathrm{lb}(13607.77 \mathrm{gm})$

On vellum in heavy 19th-c. binding:

ca. $50 \mathrm{lb}$ (22679.62 gm) 
University of Texas copy

(Reported on Exlibris, 2 February 2006)

2 vols on paper

Vol. I: ca. $14 \mathrm{lb}(6350 \mathrm{gm})$

Vol. II: ca. $13 \mathrm{lb} 14 \mathrm{oz}(6294 \mathrm{gm})$

Legal-size Hollinger Box containing 20th-c. typescripts, many on onion-skin paper, in legal-size folders

$4309.12 \mathrm{gm}(9 \mathrm{lb} 8 \mathrm{oz})$

Letter-size Hollinger Box containing 20th-c. typescripts, memos, etc., in letter-size folders

$4535.92 \mathrm{gm}(10 \mathrm{lb})$

Letter-size Hollinger Box containing $8 \times 10$ b\&w glossy photographers in folders $6350.29 \mathrm{gm}(14 \mathrm{lb})$

Envelope of 76 early 19 th c. Mexican broadsides (all approximately 32 x $22 \mathrm{~cm}$ )

$320.29 \mathrm{gm}(11 \mathrm{oz})$

$316.60 \mathrm{gm}$ (with one removed) $(11 \mathrm{oz})$

Storage carton containing Bolivian mss, 1606-1927, but predominantly pre-1826, in legal-size folders

$10092.43 \mathrm{gm}(22 \mathrm{lb} 4 \mathrm{oz})$

\section{INDEX TO ADVERTISERS}

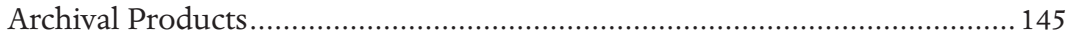

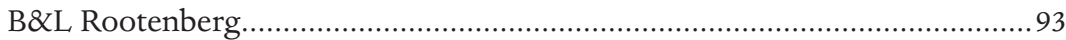

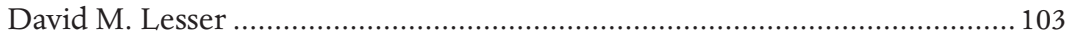

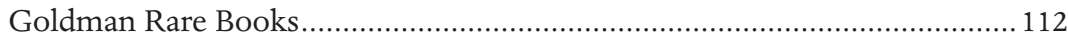

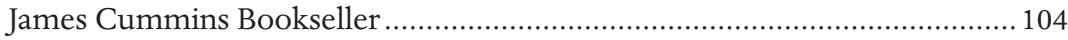

Jonathan Potter, Ltd............................................................................. 91

Martayan Lan ............................................................................... cover 2

Philadelphia Rare Books ...................................................................... cover 4

Priscilla Juvelis.............................................................................. cover 3

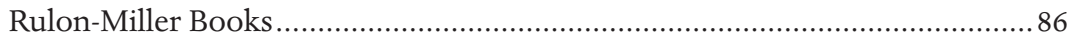

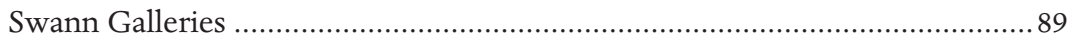

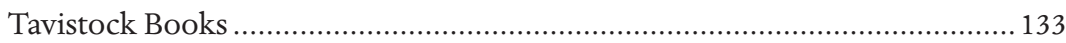




\section{Appendix II Materials Vandalized By Gilbert Bland}

\section{University of Delaware}

John Oldmixon. Das Britische Reich in America ... Lemgo: Meyer, 1744.

Bland excised Herman Moll, "Eine Neue Charte von America," 21.3 x $48.7 \mathrm{~cm}$

With map $1113.02 \mathrm{gm}(2 \mathrm{lb} 8 \mathrm{oz})$

Without map $1103.96 \mathrm{gm}(2 \mathrm{lb} 7 \mathrm{oz})$

Thomas Jeffreys. Natural and Civil History of the French Dominions in North \& South America ... London: Jeffreys, 1760.

Bland excised "North America from the French of Mr. D'Anville" (47.5 x $57 \mathrm{~cm})$

$22.15 \mathrm{gm}(.64 \mathrm{oz})$

(Entire volume was too heavy for the small scale being used.)

\section{University of North Carolina at Chapel Hill}

Mark Catesby. The Natural History of Carolina, Florida, and the Bahama Islands ...

London: White, 1771. 2 vols.

Bland removed from Vol. 1: "Map of Carolina, Florida, and the Bahama Islands" (52 x $68.5 \mathrm{~cm}) 47.20 \mathrm{gm}(1.6 \mathrm{oz})$

(Entire volume was too heavy for the small scale being used.) 